\title{
PROBABILISTIC EVALUATION OF EUROCODE 5 FIRE DESIGN CRITERIA OF A TIMBER PORTAL FRAME
}

\author{
J. M. Kaura ${ }^{1}$, I. Abubakar², U. Hassan ${ }^{3}$ and I. Aliyu ${ }^{4}$ \\ 1,2,4 DePARTMENT OF Civil ENGINEERING, AHMADU BELlo UNIVERSITY, ZARIA. NIGERIA \\ 3DANTATA AND SAWOE, NigERIA LimitED, KANO. NIGERIA \\ E-mail Addresses:1 jmkaura@abu.edu.ng,2idrcivil1@gmail.com,3 hassanmmd@yahoo.com, \\ 4ibrahimaliyu67@yahoo.com
}

\begin{abstract}
Structural reliability analysis for a three-hinge timber portal frame subjected to fire was undertaken. Eight modes of failure were identified for the frame and limit state function was formulated for each failure mode. The limit state functions were based on the Eurocode 5 design criteria. Uncertainties in the timber material properties were generated from laboratory test results performed on five commonly used timber species in Nigeria, namely Alstonia boonei (Ahun), Triplochiton Scleroxylon (Obeche), Terminalia Ivorensis (Idigbo), Terminalia superba (Afara) and Lophira Alata (Ekki). Uncertainties in loading and geometrical properties were obtained from international references. The limit state functions were evaluated using nonlinear constrained optimization technique. The optimization was executed using Genetic Algorithms(GA) based First Order Reliability Method (FORM) algorithm, through a developed computer programme in MATLAB. The results indicated that, the predominant mode of failure for a three-hinged timber portal frame in fire is the failure of the rafter-column connection that resulted to least safety levels for all the considered fire exposure times. Also, it was observed that at the critical mode of failure the portal frame can sustain fire for up to 50 minutes before failure, however, the target safety index of 3.8 recommended in the Eurocode can only be achieved at fire exposure time less than or equal to 25 minutes.
\end{abstract}

Keywords: Critical mode, Eurocode 5, fire, safety index, genetic algorithms

\section{INTRODUCTION}

One of the most prevalent questions that arise with regards to timber buildings worldwide is the question of fire safety [11]. A timber structure can be designed to be as economical, as structurally sound and as aesthetically pleasing as concrete and steel counterparts, but without addressing the issue of fire safety these facts hold little weight when a decision is made on what material to build with. The general perception of the public is that timber is combustible, therefore it is considered to be more dangerous to use than steel or concrete [13]. Fire is an emotive subject and is one of the first issues raised when timber frame construction is discussed. Comparative fire tests showed that, when concrete has perished and steel melted in fire, timber can still take a large load [10].

Timber has a high and predictable performance in fire, because timber chars at a slow and known rate [5]. In one important aspect of performance, namely the maintenance of strength with increasing temperature over time, wood performs well. This is due to the fact that timber chars at a constant rate throughout a fire; the formation of this char protects the un-burnt timber underneath.

The risk of failure of timber structures in fire can be triggered by the presence of uncertainties within the structural design parameters. The Eurocode 5 [4] design criteria for timber structures do not adequately address the issue regarding these uncertainties. The code is semi-probabilistic, in which, the issues of uncertainties are assumed to be explicitly accommodated within boxed values of deterministic partial safety factors applied to both loading and resistance. Safe timber structures can be designed with the Eurocode 5 [4], the probability of failure is however unknown. Structural resistance and the applied loading are functions of several design variables, each with its own inherent uncertainty. The 
best approach therefore, is to consider each design variable alone when modeling uncertainties. Several recent attempts were made to accommodate the uncertainties in structural analysis and design; particularly for timber structures, such as in [1], 17], [18], [19], [20], [21], [22].

Portal frames are large span structures suitable as workshops in factories and academic environments. The Eurocode emphasizes on the issues of structural robustness. Industrial portal frames need to be designed to be highly robust and durable in fire. With this in mind, this paper present reliability-based analysis of the Eurocode 5 [4] [5] design criteria for a timber portal frame subjected to fire.

\section{THE EUROCODE 5 FIRE DESIGN CRITERIA}

The mechanical resistance of timber member in fire according to Eurocode 5 [5] is giving by equation 1.0:

$\mathrm{f}_{\mathrm{d}, \mathrm{fi}}=\mathrm{k}_{\text {mod, }, \mathrm{i}} \mathrm{x} \frac{\mathrm{f}_{20}}{\gamma}$

where $\mathrm{f}_{20}$ is the $20 \%$ fractile value of the mechanical resistance distribution in normal temperature condition. $\gamma=1.0$ is the partial safety factor for timber in fire and $\mathrm{k}_{\text {mod,fi }}$ is the modification factor for fire. The action is obtained from a simplified procedure as:

$\mathrm{E}_{\mathrm{d}, \mathrm{fi}}=\eta_{\mathrm{fi}} \mathrm{E}_{\mathrm{d}}$

Where, $E_{d, f i}$ is the design action effect in fire, $E_{d}$ is the design effect of action in normal temperature design and $\eta_{\mathrm{fi}}$ is the reduction factor for the design load in fire situation.

The design charring depth is giving by:

$\mathrm{d}_{\text {char, } \mathrm{o}}=\beta_{\mathrm{n}} \mathrm{t}$

Where $d_{\text {char,o }}$ is the design charring depth for onedimensional charring, $\beta_{0}$ is one dimensional design charring rate under standard fire condition, $=0.7$ $\mathrm{mm} / \mathrm{min}$

\section{SETUP OF THE RELIABILITY ANALYSIS}

\subsection{The Structural Model}

A three-hinged timber portal frame was analysed in this paper (Figure 1). Portal frames are very important structures suitable for factories and workshops where large space is normally required. Based on the requirement of structural robustness in the Eurocode 0 [3], the fire endurance of this type of structure need to be predicted. The idealization of the three-hinged frame results into a statically determinate structure of which analysis was made by considering its force and moment equilibrium. Bending moment is zero at the supports and the ridge, and critical at the rafter-column joints. Both the rafter and the column were designed to resist axial forces, bending moment and flexural buckling.

The structural reliability analysis of the frame was undertaken through a developed MATLAB programme, based on First Order Reliability Method (FORM) with Genetic Algorithms (GA). Eight failure modes were identified as follows:

1. Member axial compression failure

2. Member bending failure

3. Member flexural buckling failure

4. Rafter-column connection failure

5. Column base failure

6. Member deflection failure

7. Overall frame sway failure

8. Frame apex connection failure

\subsection{Frame Geometry}

The three-hinged portal frame geometry was adopted from [24]. The span and the height of the frame are 6.0 $\mathrm{m}$ and $12.0 \mathrm{~m}$ respectively. The roof slope is approximately $19.80^{\circ}$. The maximum loading width is $3.0 \mathrm{~m}$. The column and rafter members were of the same thickness of $200 \mathrm{~mm}$. The maximum crosssectional height of members was taken as the design criteria as done in most studies in reliability-based analysis and design of timber structures and components such as [1].

\subsection{Effects of Actions}

The frame is exposed to the self weight of roof and variable action. The action effects of the actions considered in the analysis consist of an axial force, $\mathrm{N}$ and bending moment $\mathrm{M}$, in the design calculation, the axial force and bending moment were represented by the design values $\mathrm{N}_{\mathrm{d}}$ and $\mathrm{M}_{\mathrm{d}}$. The combination of action is determined considering expression (6.10b) given in the Eurocode 1990 [3]. Considering the imposed load as the leading variable action, it follows that:

$$
\begin{aligned}
\mathrm{N}_{\mathrm{d}}=\xi \gamma_{\mathrm{G}}\left(\mathrm{N}_{\text {frame, } \mathrm{k}}+\mathrm{N}_{\text {roof, } \mathrm{k}}\right) & \\
& +\gamma_{\mathrm{Q}}\left(\mathrm{N}_{\text {imposed, } \mathrm{k}}+\mathrm{N} \psi_{0, \mathrm{~W}} \mathrm{~N}_{\text {wind, } \mathrm{k}}\right) \\
\mathrm{M}_{\mathrm{d}}=\xi \gamma_{\mathrm{G}}\left(\mathrm{M}_{\text {frame,k }}+\mathrm{M}_{\text {roof, } \mathrm{k}}\right) & \\
& +\gamma_{\mathrm{Q}}\left(\mathrm{M}_{\text {imposed, }}+\mathrm{M} \psi_{0, \mathrm{~W}} \mathrm{M}_{\text {wind, } \mathrm{k}}\right)
\end{aligned}
$$

Where $\xi=0.85$ is the reduction factor for permanent action, $\gamma_{\mathrm{G}}=1.35$ is the partial safety factor for permanent action, $\gamma_{Q}=1.5$ is the partial safety factor for variable actions and $\psi_{0, \mathrm{w}}=0.6$ is the factor for the combination value of the wind action, $\mathrm{N}_{\text {frame, } \mathrm{k},} \mathrm{N}_{\text {roof, } \mathrm{k},}$ $\mathrm{N}_{\text {imposed,k, }} \mathrm{N}_{\text {wind,k }}$ are characteristic values of the axial forces due to self weight of the frame, self weight of the roof, imposed load and wind load respectively, 
$\mathrm{M}_{\text {frame,k, }}, \mathrm{M}_{\text {roof, } \mathrm{k},} \mathrm{M}_{\mathrm{imposed}, \mathrm{k}}, \mathrm{M}_{\text {wind,k }}$ are the characteristic values of the bending moments due to self weight of the frame, self weight of the roof, imposed load and wind load respectively.

The imposed load on roofs was taken a $0.75 \mathrm{~N} / \mathrm{mm}^{2}$ for roofs without access based on Eurocodes 1-1 [26]. Wind load on the roof and frame were generated by a MATLAB function 'windload.m' (Appendix A), developed in the study based on the requirement of the Eurocode 1-4 [27]. The programme uses meteorological data for wind load reported in the work of Onundi [28].

The dead load for the frame was based on a variable to total load ratio of 0.8 (for light weight timber structures) as reported in [17], [25], which is given by:

$\chi=\frac{Q_{\mathrm{k}}+\mathrm{W}_{\mathrm{k}}}{\mathrm{G}_{\mathrm{k}}+\mathrm{Q}_{\mathrm{k}}+\mathrm{W}_{\mathrm{k}}}=0.8$

Where, $\chi$ is the variable to total load ratio, $G_{k}, Q_{k}$ and $\mathrm{W}_{\mathrm{k}}$ are characteristics dead, imposed and wind loads respectively. The load input process is implements within the main program 'genehunter.m' (Appendic B)

\subsection{Limit State Functions for the Various Failure Modes}

Limit state functions were developed for each of the eight failure modes. The limit state functions for the first three failure modes are as follows:

Limit state function for the axial compression failure mode:

$G(X)=\frac{\left(k_{\text {mod }} f_{c, 0, k}\right)}{\gamma_{m}}-\sigma_{c, 0, d}$

Limit state function for the bending failure mode:

$G(X)=\frac{\left(k_{\text {mod }} f_{m, k}\right)}{\gamma_{m}}-\sigma_{m, d}$

Limit state function for the flexural buckling:
$G(X)=1-\frac{\left(\sigma_{m, d}\right)}{\left(f_{m, d}\right)}+\frac{\left(\sigma_{c, 0, d}\right)}{\left(k_{c} f_{c, o, d}\right)}$

where $\mathrm{k}_{\text {mod }}$ is the modification factor for load duration, $\mathrm{f}_{\mathrm{c}, \mathrm{o}, \mathrm{k}}$ and $\mathrm{f}_{\mathrm{c}, \mathrm{o}, \mathrm{d}}$ are the characteristic and design compression strengths parallel to grain, $\sigma_{\mathrm{c}, \mathrm{o}, \mathrm{k}}, \sigma_{\mathrm{c}, \mathrm{o}, \mathrm{d}}$ are the characteristic and design compressive stresses parallel to grain, $\mathrm{f}_{\mathrm{m}, \mathrm{k}}$ and $\mathrm{f}_{\mathrm{m}, \mathrm{d}}$ are the characteristic and design bending strengths, $\sigma_{\mathrm{m}, \mathrm{k}}, \sigma_{\mathrm{m}, \mathrm{d}}$ are the characteristic and design bending stresses, $\gamma_{\mathrm{m}}$ is the material safety factor, $\mathrm{k}_{\mathrm{c}}$ is the reduction factor for flexural buckling,

\subsection{Evaluation of the Limit State Function}

Genetic algorithms based First Order Reliability Method (GAFORM) was used to evaluate the eight limit state functions. Genetic algorithms (GA) are adaptive heuristic search algorithms based on the evolutionary ideas of natural selection and genetics. They represent an intelligent exploitation of a random search used to solve optimization problems [16]. The basic techniques of the GA are designed to simulate processes in natural systems necessary for evolution, especially those that follow the Charles Darwins's principles of survival of the fittest. Genetic algorithms evaluate the limit state functions and computing safety indices by using the genetic search technique based on the natural selection process by following a search path until failure is reached [2], [15], [16]. Comparing with the conventional FORM, the genetic algorithm has advantage that it does not involve the difficulties of computing the derivatives of limit state functions with respect to random variables and has the capability of identifying global optimum values of the limit state functions.

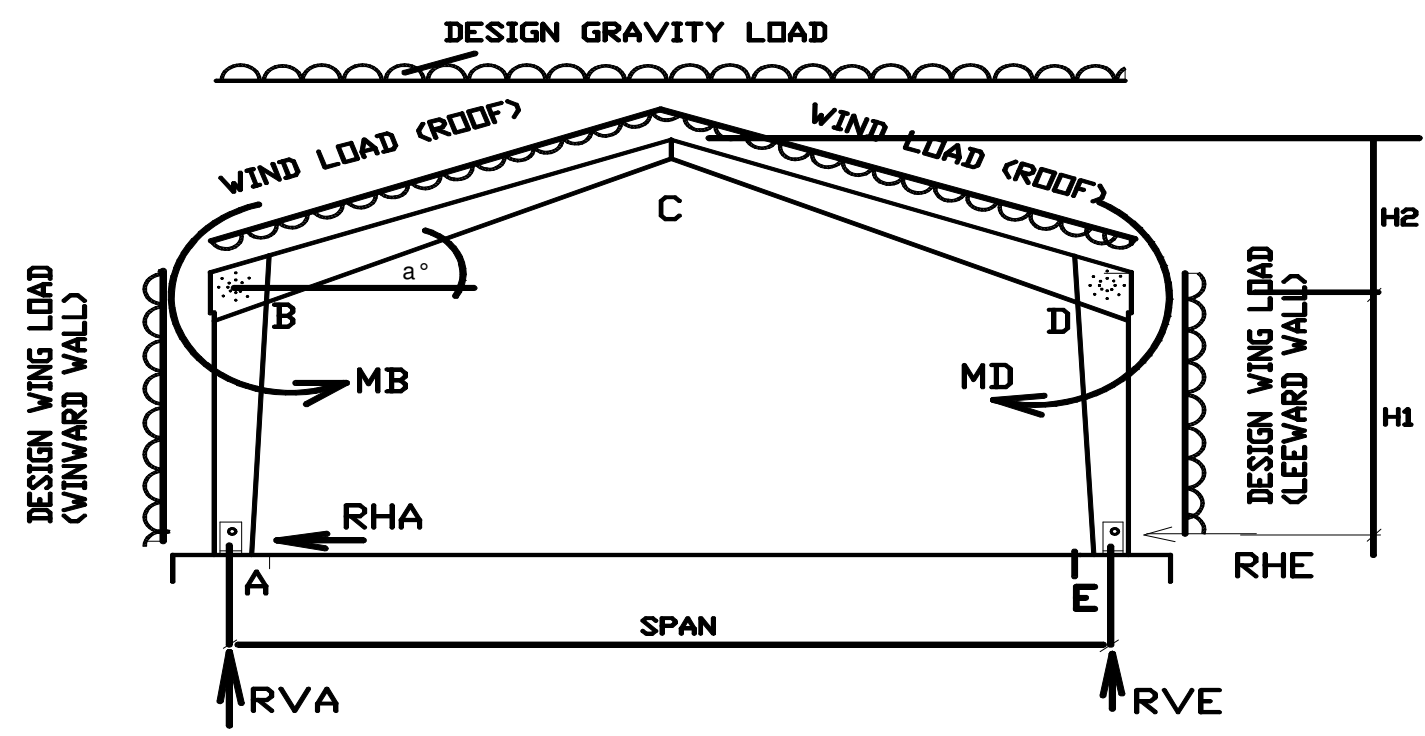

Figure 1. Three hinge portal frame considered for analysis 
The imposed load on roofs was taken a $0.75 \mathrm{~N} / \mathrm{mm}^{2}$ for roofs without access based on Eurocodes 1-1 [26]. Wind load on the roof and frame were generated by a MATLAB function 'windload.m' (Appendix A), developed in the study based on the requirement of the Eurocode 1-4 [27]. The programme uses meteorological data for wind load reported in the work of Onundi [28].

The dead load for the frame was based on a variable to total load ratio of 0.8 (for light weight timber structures) as reported in [17], [25], which is given by:

$\chi=\frac{\mathrm{Q}_{\mathrm{k}}+\mathrm{W}_{\mathrm{k}}}{\mathrm{G}_{\mathrm{k}}+\mathrm{Q}_{\mathrm{k}}+\mathrm{W}_{\mathrm{k}}}=0.8$

Where, $\chi$ is the variable to total load ratio, $G_{k}, Q_{k}$ and $\mathrm{W}_{\mathrm{k}}$ are characteristics dead, imposed and wind loads respectively. The load input process is implements within the main program 'genehunter.m' (Appendic B)

\subsection{Limit State Functions for the Various Failure Modes}

Limit state functions were developed for each of the eight failure modes. The limit state functions for the first three failure modes are as follows:

Limit state function for the axial compression failure mode:

$G(X)=\frac{\left(k_{\bmod } f_{c, 0, k}\right)}{\gamma_{m}}-\sigma_{c, o, d}$

Limit state function for the bending failure mode:

$G(X)=\frac{\left(k_{m o d} f_{m, k}\right)}{\gamma_{m}}-\sigma_{m, d}$

Limit state function for the flexural buckling:

$G(X)=1-\frac{\left(\sigma_{m, d}\right)}{\left(f_{m, d}\right)}+\frac{\left(\sigma_{c, o, d}\right)}{\left(k_{c} f_{c, o, d}\right)}$

where $\mathrm{k}_{\mathrm{mod}}$ is the modification factor for load duration, $\mathrm{f}_{\mathrm{c}, \mathrm{o}, \mathrm{k}}$ and $\mathrm{f}_{\mathrm{c}, \mathrm{o}, \mathrm{d}}$ are the characteristic and design compression strengths parallel to grain, $\sigma_{c, 0, k}, \sigma_{c, 0, d}$ are the characteristic and design compressive stresses parallel to grain, $\mathrm{f}_{\mathrm{m}, \mathrm{k}}$ and $\mathrm{f}_{\mathrm{m}, \mathrm{d}}$ are the characteristic and design bending strengths, $\sigma_{\mathrm{m}, \mathrm{k},} \sigma_{\mathrm{m}, \mathrm{d}}$ are the characteristic and design bending stresses, $\gamma_{\mathrm{m}}$ is the material safety factor, $k_{c}$ is the reduction factor for flexural buckling,

\subsection{Evaluation of the Limit State Function}

Genetic algorithms based First Order Reliability Method (GAFORM) was used to evaluate the eight limit state functions. Genetic algorithms (GA) are adaptive heuristic search algorithms based on the evolutionary ideas of natural selection and genetics. They represent an intelligent exploitation of a random search used to solve optimization problems [16]. The basic techniques of the GA are designed to simulate processes in natural systems necessary for evolution, especially those that follow the Charles Darwins's principles of survival of the fittest. Genetic algorithms evaluate the limit state functions and computing safety indices by using the genetic search technique based on the natural selection process by following a search path until failure is reached [2], [15], [16]. Comparing with the conventional FORM, the genetic algorithm has advantage that it does not involve the difficulties of computing the derivatives of limit state functions with respect to random variables and has the capability of identifying global optimum values of the limit state functions. A genetic algorithm-based reliability problem can be formulated in the following form:

Minimise $\beta=\|\| \mu\|\|^{2}=\mu^{\mathrm{T}}$. $\mu$

Subject to $g(\mu)=0$

where, $\mu$ is the vector of standard normal variable, $\mu^{\mathrm{T}}$ is the transpose of $\mu, g(\mu)$ is the limit state function, $\beta$ is the reliability index. The problem of equation 22.0 is a constrained nonlinear optimization problem. Various GA, operators; selection, reproduction, crossover and mutation are administered iteratively through generations, until either of the following stopping criteria is achieved.

1. The average reliability index of the current generation does not show significant improvement over the former generation.

$\gamma \beta^{(\mathrm{k}+1) \text { generation }}>\gamma \beta^{\mathrm{kg} \text { generation. }}$

$\gamma$ can be set to 0.95 [16]

2. The first three different minimum safety indices of the current generation remain the same as those of the previous generation.

The overall operation are implemented through a developed MATLAB computer programme 'genehunter.m'.

\subsection{Statistical Parameters of Random Variables}

Structural reliability analysis requires data on the statistical parameters of the basic design variables. The parameters include the mean values, coefficient of variation and theoretical distribution models. The statistics of the material properties of timber in this study were generated from laboratory experiments for five commercial timber species in Nigeria. The species are; Alstonia boonei (Ahun), Triplochiton Scleroxylon (Obeche), Terminalia Ivorensis (Idigbo), Terminalia superba (Afara) and Lophira Alata (Ekki). The laboratory experiments were conducted in accordance with EN 408 [6] and EN 384 [7]. Only the reference material properties (density, bending 
strength and bending modulus of elasticity) were generated. Other properties such as tension and compression strength parallel and perpendicular to grain and shear strength were derived from the reference material properties using the property relation in EN 384 [7] and JCSS [12]. Statistical properties for loading and member dimensions are also required. Actual data on dead and live load uncertainties is not available for the Nigerian reality. The dead and live load statistics used in this research are based on the data reported elsewhere [9], [14]. The statistical parameters are presented in Tables 1 to 3.

\section{RESULTS AND DISCUSSION}

Figure 3. shows the variation of safety index with fire exposure time due to axial compression. The frame was subjected to one hour fire exposure. It is clear from the plots that, for all the five timber specie (Alstonia boonei, Triplochiton Scleroxylon, Terminalia Ivorensis, Terminalia superba and Lophira Alata) considered at the experimental stage, safety index increases with increasing fire exposure time. From the laboratory experiment, Alstonia boonei was found to be the weakest in terms of strength, belonging to EN 338 [8] timber strength class D18, while Lophira Alata was found to be the strongest, belonging to EN 338 [8] strength class D60. It is observed from the plot, that compressive stress durability of timber structural members in fire is higher for timber specie of higher strength class (grade). For example, Frame made with Triplochiton Scleroxylon has safety index for compressive failure mode of 7.6 before the frame was exposed to fire. However after 60 minute of fire exposure, the safety index changed to 3.0 representing about $60 \%$ drop in safety level. Frame made with Triplochiton Scleroxylon is least safe for compression failure mode, while Lophira Alata frame displayed highest safety level for the compression mode of failure.

Table 1: Statistical Parameters for the Reference Material Properties

\begin{tabular}{llcrr}
\hline \multicolumn{1}{c}{ Variable } & Mean & $\begin{array}{c}\text { Coefficient of } \\
\text { variation }\end{array}$ & $\begin{array}{c}\text { Distribution } \\
\text { model }\end{array}$ & Reference \\
\hline Bending strength, $\mathrm{f}_{\mathrm{m}}\left(\mathrm{N} / \mathrm{mm}^{2}\right)$ & $43-98$ & $0.12-0.19$ & Lognormal & Experiment \\
$\begin{array}{l}\text { Bending modulus of elasticity, } \mathrm{E}_{\mathrm{m}} \\
\left(\mathrm{N} / \mathrm{mm}^{2}\right)\end{array}$ & $6137-$ & $0.06-0.27$ & Lognormal & Experiment \\
Density, Density, $\rho_{\mathrm{den}}\left(\mathrm{kg} / \mathrm{m}^{3}\right)$ & 21350 & & & \\
\end{tabular}

Table 2: Statistical Parameters for the Derived Material Properties

\begin{tabular}{|c|c|c|c|c|}
\hline Variable & Mean & $\begin{array}{c}\text { Coefficient of } \\
\text { variation }\end{array}$ & Distribution model & Reference \\
\hline $\begin{array}{l}\text { Tensile strength parallel to grain, } \mathrm{f}_{\mathrm{t}, 0} \\
\left(\mathrm{~N} / \mathrm{mm}^{2}\right)\end{array}$ & $0.6 \mathrm{f}_{\mathrm{m}}$ & $1.2 \mathrm{COVf}_{\mathrm{m}}$ & Lognormal & [7], [12] \\
\hline $\begin{array}{l}\text { Tensile strength perpendicular to } \\
\text { grain, } \mathrm{f}_{\mathrm{t}, 90}\left(\mathrm{~N} / \mathrm{mm}^{2}\right)\end{array}$ & $0.015 \rho_{\text {den }}$ & $2.5 \mathrm{COV} \rho_{\mathrm{den}}$ & Lognormal & [7], [12] \\
\hline $\begin{array}{l}\text { Compressive strength parallel to } \\
\text { grain, } \mathrm{f}_{\mathrm{c}, \mathrm{o}}\left(\mathrm{N} / \mathrm{mm}^{2}\right)\end{array}$ & $5 \mathrm{f}_{\mathrm{m}} 0.45$ & $0.8 \mathrm{COVf}_{\mathrm{fm}}$ & Lognormal & {$[7],[12]$} \\
\hline $\begin{array}{l}\text { Compressive strength perpendicular } \\
\text { to grain, } \mathrm{f}_{\mathrm{c}, 90}\left(\mathrm{~N} / \mathrm{mm}^{2}\right)\end{array}$ & $0.008 \rho_{\text {den }}$ & $\operatorname{coV} \rho_{\text {den }}$ & Lognormal & [7], [12] \\
\hline Shear strength, $\mathrm{f}_{\mathrm{v}}\left(\mathrm{N} / \mathrm{mm}^{2}\right)$ & $0.2 \mathrm{f}_{\mathrm{m}} 0.8$ & $\mathrm{COVf}_{\mathrm{m}}$ & Lognormal & [7], [12] \\
\hline Model uncertainty for strength, $\theta_{R}$ & 1.0 & 0.1 & Lognormal & [1] \\
\hline
\end{tabular}

Table 3: Statistical Parameters for Loading

\begin{tabular}{|c|c|c|c|c|}
\hline Variable & Mean & $\begin{array}{c}\text { Coefficient of } \\
\text { variation }\end{array}$ & Distribution model & Reference \\
\hline Dead load G $\left(\mathrm{kN} / \mathrm{m}^{2}\right)$ & $1.05 \mathrm{G}$ & 0.10 & Normal & [9]. [14] \\
\hline Imposed load Q $\left(\mathrm{kN} / \mathrm{m}^{2}\right.$ & $1.0 \mathrm{Q}$ & 0.25 & Gumbel & [9]. [14] \\
\hline Wind load $\mathrm{W}\left(\mathrm{kN} / \mathrm{mm}^{2}\right)$ & $0.90 \mathrm{~W}$ & 0.34 & Gumbel & [9]. [14] \\
\hline Load duration factor $\mathrm{k}_{\bmod }$ & $1.0 \mathrm{k}_{\mathrm{mod}}$ & 0.15 & Lognormal & [1] \\
\hline Depth, h (mm) & $\begin{array}{c}415- \\
570 \mathrm{~mm}\end{array}$ & 0.06 & Normal & [1] \\
\hline Thickness, $\mathrm{t}(\mathrm{mm})$ & $100 \mathrm{~mm}$ & 0.06 & Normal & [1] \\
\hline Model uncertainty for load, $\theta_{s}$ & 1.0 & 0.1 & Lognormal & [1] \\
\hline
\end{tabular}


Similar Trends of Figure 2 was observed in Figure 3. The plot shows the relationship between safety index and fire exposure time for bending mode of failure. In this mode of failure, frame made with Alstonia boonei is the weakest for bending mode of failure with safety index ranging from 7.6 to 3.0 at 0 and 60 minutes fire exposure time respectively. Also, frame made with Terminalia superba displayed highest safety indices at all values of fire exposure time. It is clear that the safety index for compression and bending modes of failure are very high at normal temperature. Considering the target safety index of 3.8 specified in the Eurocode 0 [3], it can be deduced that, based on the results obtained from this study, the Eurocode 5 design criteria for compression and bending is adequate under fire exposure time up to 60 minutes, for Alstonia boonei and Triplochiton Scleroxylon timber species and beyond 60 minutes for the other timber species.

Figure 4.shows the relationship between safety index and fire exposure time for the buckling mode of failure. In this plot, Alstonia boonei frame was also found to be the weakest for buckling mode of failure and the strongest frame for buckling mode of failure is that made with Lophira Alata timber. Comparing the buckling mode with compression and bending failure modes it is clear that, buckling mode of failure results to higher safety indices at higher exposure time.

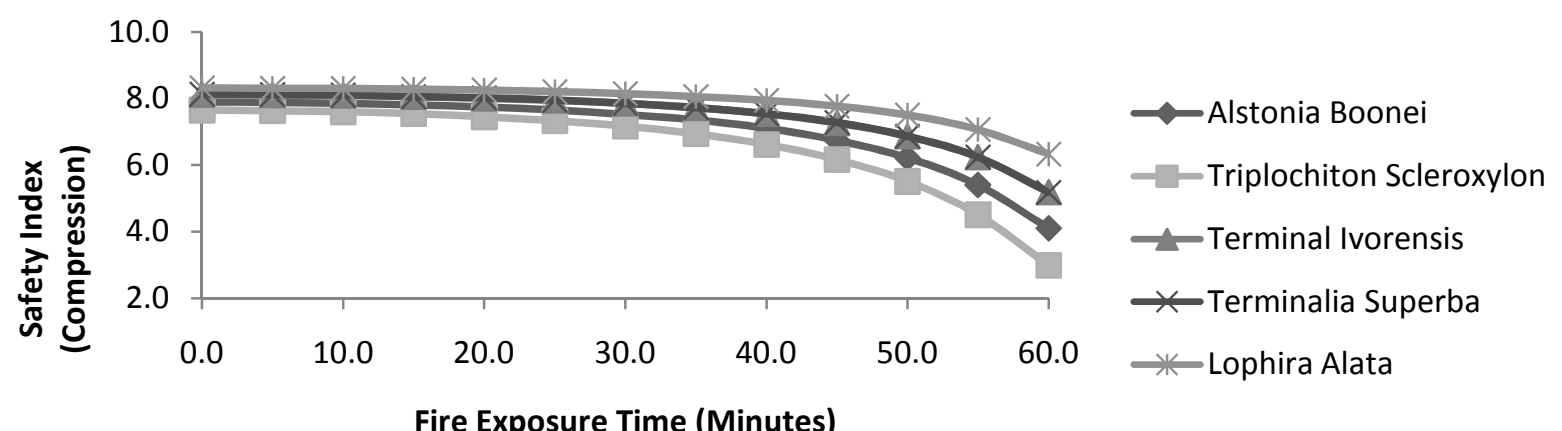

Figure. 2: Variation of safety index with fire exposure time for compression failure mode

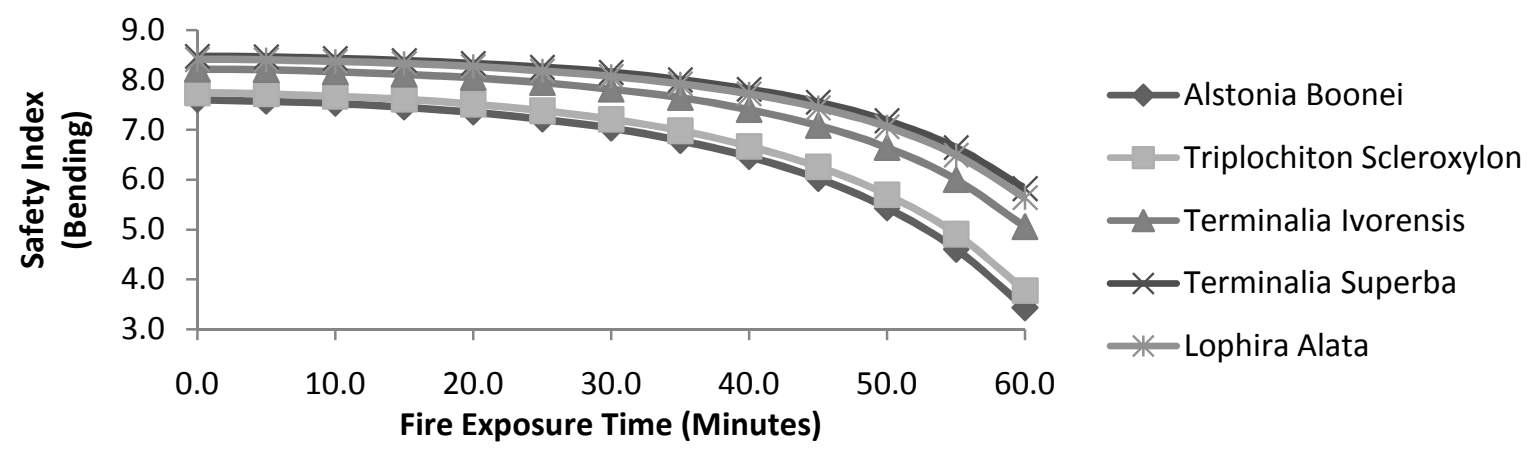

Figure 3: Variation of safety index with fire exposure time for bending failure mode

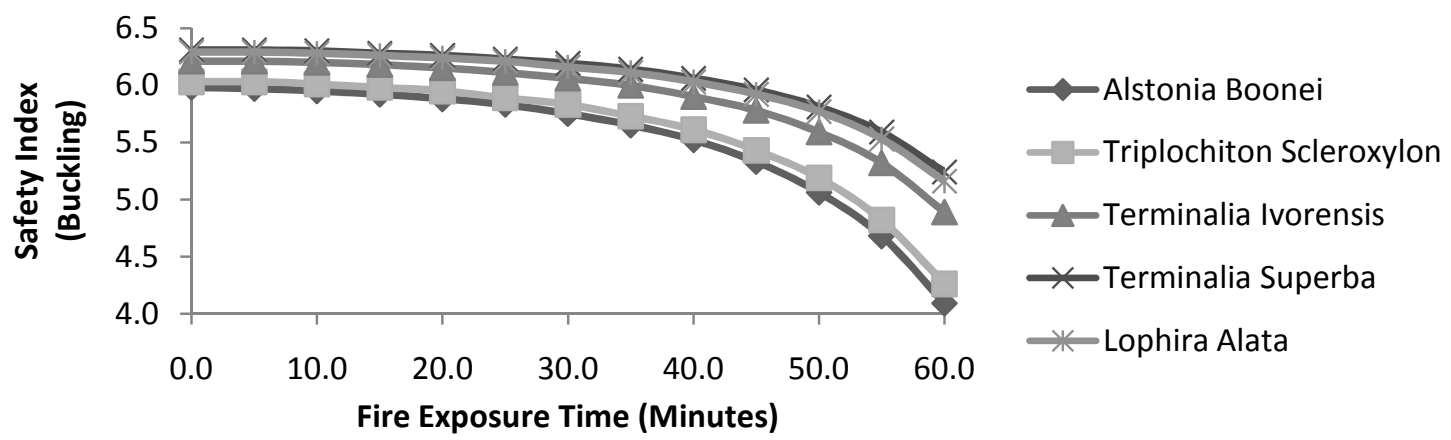

Figure 4: Variation of safety index with fire exposure time for buckling failure mode 
Example at 60 minutes fire exposure, the safety indices for Lophira Alata frame for compression, bending and buckling modes of failure are 6.4, 5.6 and 5.4 respectively, which are higher than the corresponding safety indices obtained for axial compression and bending modes of failure.

Figure 5 shows the relationship between safety index and fire exposure time for the rafter-column connection failure mode. As against what was observed in the previous modes of failure in which, the safety indices are close for all timber species, before the frame is exposed to fire, the difference between least safety index (1.8) and the highest safety index (5.5) at 0 fire exposure time is 3.5. As the fire exposure time increased, the rafter-column connection for the Alstonia failure frame failed at 40 minute (safety index $=0$ ), and for the Lophira Alata frame, the rafter-column connection failed at 52 minutes. Although, it was established that the frame can sustain fire for up to 60 minutes without violating the limit state for compression, bending and buckling, the results for rafter-column connection had threaten such achievement limiting the maximum fire exposure time at 3.8 target safety index [3] to less than 20 minutes to Alstonia boonei, Triplochiton Scleroxylon, Terminalia Ivorensis and Terminalia superba frames, and less than 40 minutes for Lophira alata frame.
The relationship between safety index and fire exposure time for column-base failure mode is displayed in Fig, 6. The plots are similar to those of bending and compression. However, the safety indices are almost zero at 60 minutes exposure time..

The relationship between safety index and fire exposure time for the deflection mode of failure is presented in Figure 7. It is observed that deflection is also critical for portal frame under fire. At 0 exposure time, to fire the safety index is high. However, as the fire exposure time approach 60 minutes, the tendency for deflection failure became higher especially for the frame made with timber species of low grade.

Frames subjected to excessive lateral displacement are likely to fail. The tendency for this type of failure is triggered when the frame is exposed to fire as observed in Figure 8. The trend is also similar, for the frame apex connection mode of failure as shown in Figure 9.

In Figure 10, the fire resistance capacity of the portal frame made with Lophira Alata timber specie for the eight possible modes of failure were compare, in order to identify the most critical (predominant) mode of failure. It is clear from the plot that the rafter-column connect failure mode is the critical mode with least safety index at all fire exposure time

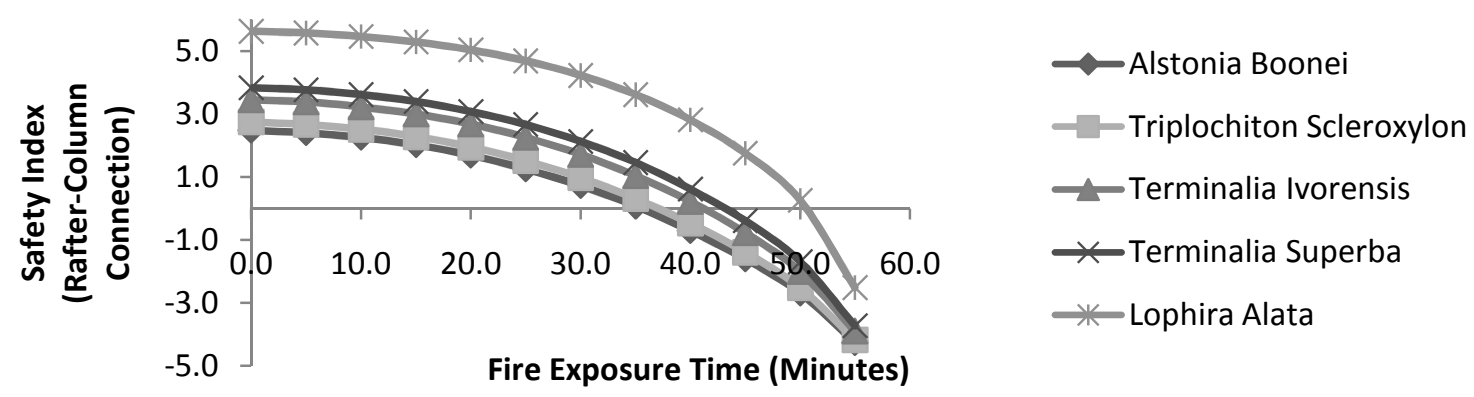

Figure 5: Variation of safety index with fire exposure time for rafter-column connection failure mode

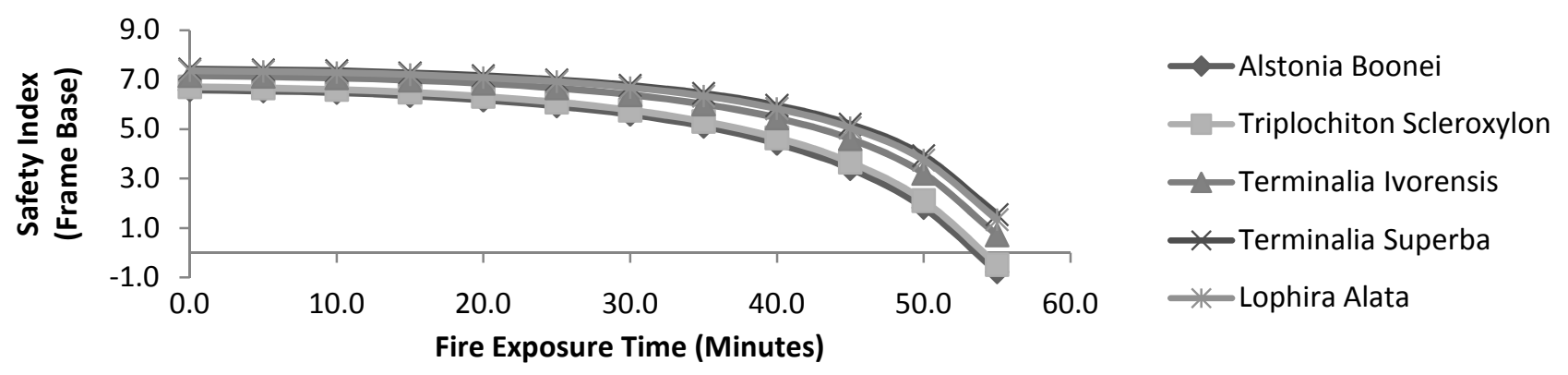

Figure 6: Variation of safety index with fire exposure time for frame column base failure mode 


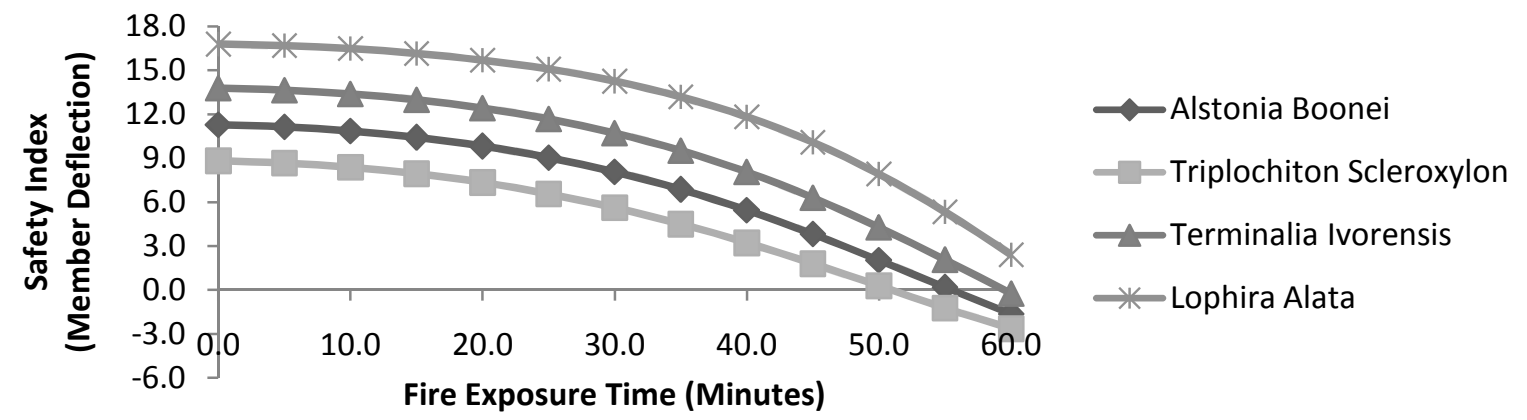

Figure 7: Variation of safety index with fire exposure time for member deflection failure mode

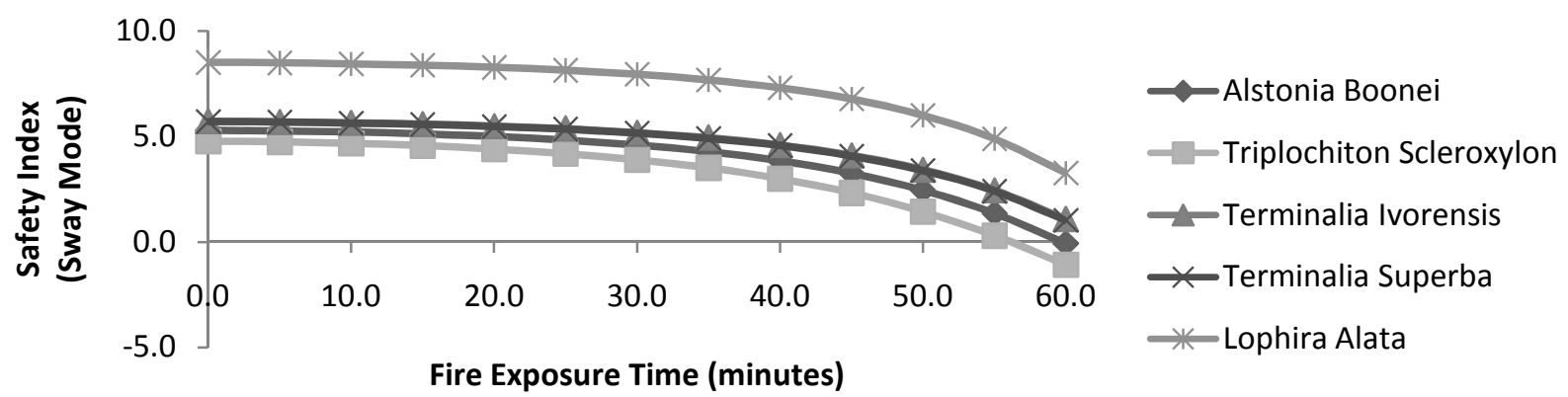

Figure 8: Variation of safety index with fire exposure time for frame failure mode due to lateral displacement

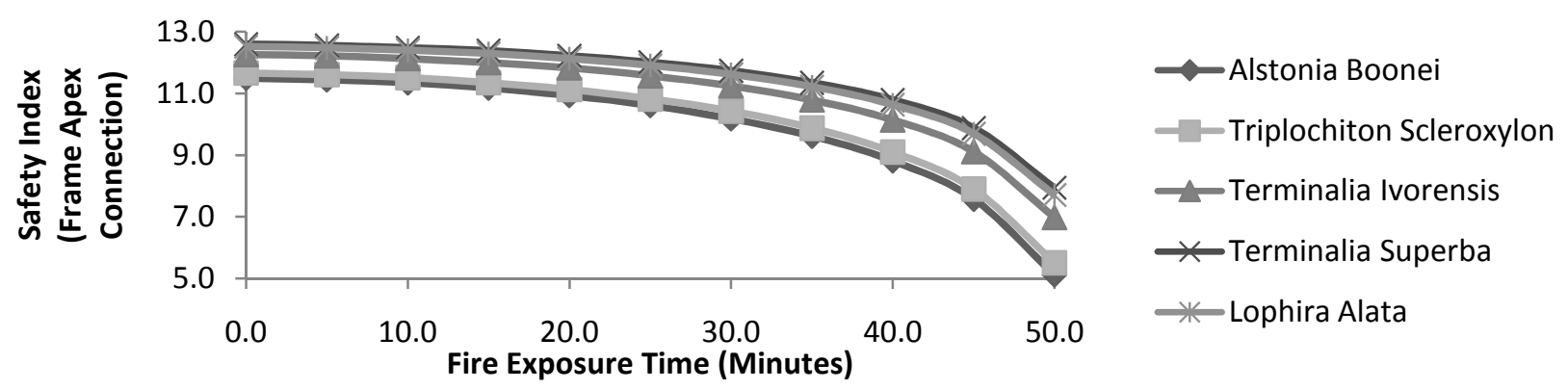

Figure 9: Variation of safety index with fire exposure time for frame apex connection failure mode

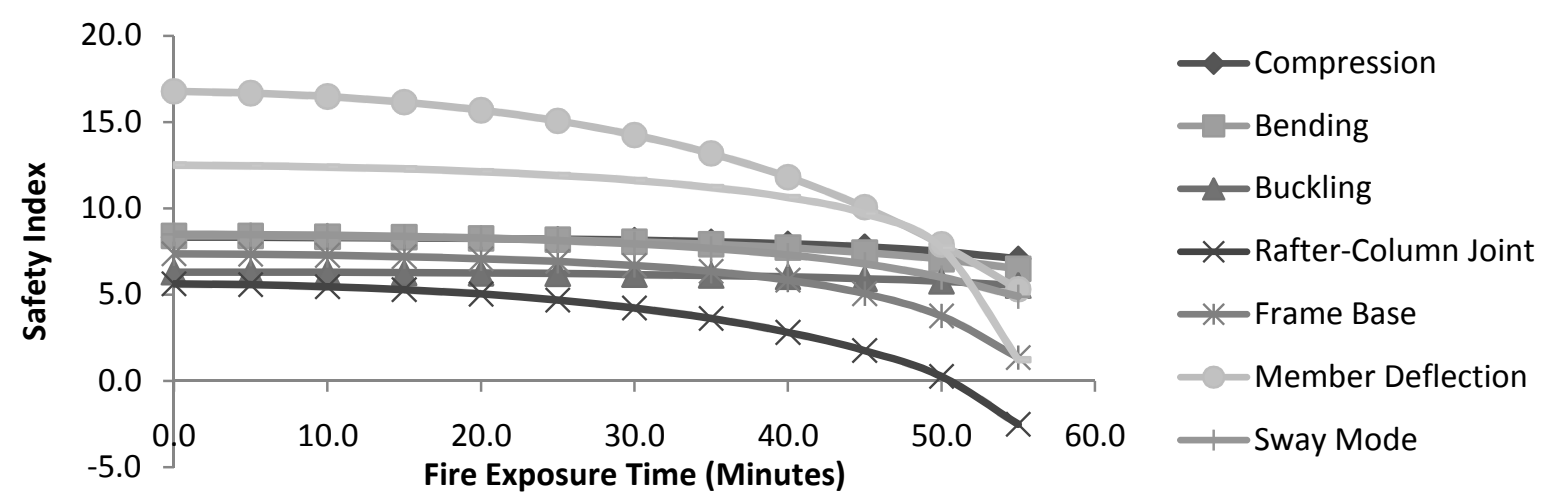

Figure 10: Variation of safety index with fire exposure time for various failure modes

\section{CONCLUSION}

A three-hinged timber portal frame was subjected to structural reliability analysis considering eight modes of failure, namely: member axial compression failure, member bending failure, member buckling failure, rafter-column connection failure, column base failure, member deflection failure, overall frame sway failure, frame apex connection failure. The results indicated that, the predominant mode of failure of a three- hinged timber portal frame in fire is the failure of the rafter-column connection that resulted to least safety levels at all fire exposure time. Also, it was observed that at the critical mode of failure, the portal frame can sustain fire for up to 50 minutes before failure, however, the target safety index of 3.8 recommended in the Eurocode 0 [3] can only be achieved at fire exposure time equal to or less than 25 minutes. 
Based on the results obtain in this study, the following recommendation are made:

i. Adequate fire protection measures should be given to the rafter-column connection, in order to increase the safety margin for timber portal frame in fire.

ii. Timber species of higher strength class, such as Lophira alata should be used for the fire endurable timber portal frame.

iii. Reliability-based approach should be accommodated in the design of timber structure in order to be able to meet the target safety level recommended in the Eurocodes

iv. As a results of large member sections required for timber portal frame as indicated by the results of reliability-based design in this study, the use of glue lamination technology is necessary for the production of the columns and the rafters.

\section{REFERENCES}

[1] Afolayan, J. 0. "Probability-based Design of Glued Thin-webbed Timber Beams", Asian Journal of Civil Engineering (Building and Housing), Vol. 25, Number 1-2, 2005, pp 57-67.

[2] Cheng, J. "Hybrid Genetic Algorithms for Structural Reliability Analysis", Computers and Structures, Vol, 85, 2007, pp. 1524-1539.

[3] Eurocode 0. Eurocode-Basis of Structural Design. British Standards, CEN Brussels, 2004.

[4] Eurocode 5, part 1-1. Eurocode 5: Design of Timber Structures-Part 1-1: General Common Rules for Buildings. CSI, Prague, December, 2004.

[5] Eurocode 5, part 1-2: Design of Timber StructuresPart 1-1: Fire Design of Timber Structures. CSI, Prague, December, 2004.

[6] EN 408. European Standard Timber StructuresStructural Timber: Determination of some Physical and Mechanical Properties, 2004, Comite European de Normalisation. Brussesls, Belgium.

[7] EN 384. Timber Structures; Structural Timber Determination of Characteristic Values of Mechanical Properties and Density, 2004, Comite European de Normalisation. Brussesls, Belgium.

[8] EN 338. Structural Timber; Strength Classes, European Committee for Standardization. Australia Standards Institute Heinestrabe 38, 1020 Wien, 2009.

[9] Ellingwood, B., Galambos, T. V., McGregor, I. G. and Cornell, C. A. Development of Reliability-Based Load Criteria for American National Standard, A58, 1980.
[10] Ideris, F., Idris, M. A., Annuar, A. R. and Kadir, A. K. "Comparison between Experimental and Simulation for the Fire Resistance of Malaysian Wood Columns (Resak)", ICCBT, 2008-B, Vol. 33, 2008, pp. 365-372.

[11] James, W. "The Fire Performance of Timber Concrete Composite Floors". Unpublished MSc Thesis. Department of Civil Engineering and Natural Resources Engineering, University oif Cantebury, Christchurch, New Zealand, 2009.

[12] JCSS "Joint Committee on Structural SafetyProbabilistic Model Code: Material Properties of Timber", 2006. http://www.jcss.ethz.ch retrieved on $3^{\text {rd }}$ February, 2013.

[13] Lina, L., Virmtas, J. and Egidijus, R. V. “On Reliability of Timber Structures Subjected to Fire", $10^{\text {th }}$ International Conference on Modern Building Materials, Structures and Techniques. Vilnius, Lithunia, 2010.

[14] McGregor, J. G. "Safety and Limit State Design for Reinforced Concrete", Canadian Journal of Civil Engineering, Vol. 10, 1976, pp. 484-513.

[15] Rackwitz, R. "Reliability Analysis, Past, Present and Future", $8^{\text {th }}$ ASCE Specialty Conference on Probabilistic Mechanics and Structural Reliability, 2002.

[16] Wang, J. and Ghosn, M., "Linkage-Shredding Genetic Algorithms for Reliability Assessment of Structural Systems", Structural Safety, Vol. 27, 2005, pp. 49-72.

[17] Ranta-Maunus, A., Fonselius, M., Kurkela, J., and Toratti, T. "Reliability Analysis of Timber Structures". VTT Research Notes 2109, Espoo, 2001.

[18] Abubakar, I., and Peter, H. B. "Failure Investigation of Reinforced Concrete Cantilever Retaining Walls", Nigerian Journal of Technology, Vol.3 Number 3, Nov, 2012, pp 248-260.

[19] Benu, M. J. "Probabilistic Failure Analysis of Solid Timber Column", Nigerian Journal of Technology, Vol. 31, Number 3, Nov. 2012, pp 405-408.

[20] Aguwa, J. "Structural Reliability of the Nigerian Grown Abura Timber Bridge Beam Subjected to Bending and Deflection", Nigerian Journal of Technology, Vol. 32, Number 2. July, 2013, pp 241252.

[21] Abejide, O. S. "Optimization of Design Formulations for Reinforced Concrete Slabs". Nigerian Journal of Technology, Vol. 33, Number 1, January, 2014, pp 19-24.

[22] Murana A. A., and Abejide, O. S. "Safety of Post-Fire Strength Capacity Prediction in Bolted Steel Joints", Nigerian Journal of Technology, Vol. 31, Number 3, Nov. 2012, pp 336-345.

[23] Abejide, O. S. "Reliability Analysis of Bending, Shear and Deflection Criteria of Reinforced Concrete Slabs", «what is the journal??» Vol 33, No 3. July, 2014, pp 394-400. 
[24] Blass, H. J., Aune, P., Choo, B. S., Golacher, R., Griffins, D. R. and Hilson, B. 0. Timber Engineering STEP 1, First Edition, Centum Hout, The Netherlands.

[25] Ranta-Maunus, A. and Toratto, T. “ Target Safety Level of Timber Structures",VTT Building and Transport, Espoo, Finland.

[26] Eurocode 1-1. Actions on Structures Part 1: Imposed Loads. General Common Rules for Buildings, CEN, Brussels.

[27] Eurocode 1-4. Actions on Structures Part 4: Wind Loads. General Common Rules for Buildings, CEN, Brussels.

[28] Onundi, L. O., Oumarou, M. B., and Philips, O. "Classification of Nigeria Wind Speed Isopleths for Structural Purposes", Continental Journal of Engineering Sciences, Vol. 4, pp 48-55.

\section{APPENDIX A: WINDLOAD.M}

function $\mathrm{WKw}=$ windload(Z,BWSPEED,XL)

$\%$ CDR is the directional factor

$\%$ CSEASON is the seasonal factor

$\% \mathrm{Z}$ is the overall height of the frame

$\%$ FRAME_LENGTH is overall length of the frame

$\%$ BWSPEED is the fundamental value of wind velocity

$\%$ BWSPEED is obtained from the Nigerian wind

$\%$ speed ISOPLETHS (Onundi et al, 2009)

$\%$ WSPEED is the basic wind velocity

$\%$

$\mathrm{CDR}=1.0$

CSEASON $=1.0$;

WSPEED $=$ BWSPEED $*$ CDR $^{*}$ CSEASON;

$\%$

$\%$ Terrain catery is generally taken as category II in accordance with

\% Eurocode 1 part 4. That is (Area with low vegetation such as grass and

$\%$ isolated obstacles (tress, buildings) with separtions of at least 20

$\%$ obstacles.

$\%$

ZNAUGHT $=0.05 ; \%$ A topography factor (Eurocode 1-4)

$\mathrm{Z} 10=0.05$

$\%$

$\%$ The next stage is to compute the wind pressure in $\mathrm{N} / \mathrm{m}^{\wedge} 2$ $\%$

AIR_DENSITY $=1.25 ; \% \mathrm{In} \mathrm{kg} / \mathrm{m}^{\wedge} 3$

WIND_PRESSURE $=0.5^{*}(\text { AIR_DENSITY })^{*}\left(\right.$ WSPEED $\left.^{\wedge} 2\right)$;

$\%$

$\%$ Next is the computation of thev mean wind velocity

$\%$ Assume that the tatal height $\mathrm{z}$ is greater than or equal to

Z_MINIMUM

$\%$

$\mathrm{XKT}=$

$\left(\left(0.19^{*}\left((\text { ZNAUGHT/Z10 })^{\wedge}(0.07)\right)\right) *(\log (\mathrm{Z} / \mathrm{ZNAUGHT}))\right)$;

TURBULENCE_FACTOR $=1.0$;

INTENSITY $=$

(7.0*TURBULENCE_FACTOR)/((log(Z/ZNAUGHT)));
$\%$

$\%$ if and only if the total height of frame is greater than or equal

$\%$ to $2 \mathrm{~m}$, and less than or equal to $200 \mathrm{~m}$. $\%$

PEAK_PRESSURE $=(1.0+$ INTENSITY $) *$ WIND_PRESSURE $*$ XKT; PRESSURE $=$ PEAK_PRESSURE $/ 1000.0 ; \%$ Pressure in $\mathrm{kN} / \mathrm{m}^{\wedge} 2$ $\%$

$\%$ Next is the determination of the externalpressure coefficients on

$\%$ vertical surfaces (Table 7.1 of the Eurocode 1 part 4 )

$\%$

ratiod $=\mathrm{Z} / \mathrm{XL}$;

$\%$ WINDWARD WALL PRESSURE COEFFICIENTS

$\%$ TABLE 7.1 (EUROCODE 1-4: 2004)

if(ratiod $<=0.25$ )

$\mathrm{XD}=0.7$;

elseif(ratiod $>0.25) \& \&($ ratiod $<1)$

$\mathrm{XD}=0.8$;

elseif(ratiod $>=1) \& \&($ ratiod $<5)$

$\mathrm{XD}=0.8$;

end

$\mathrm{WKw}=\mathrm{XD} *$ PRESSURE;

end

APPENDIX B: GENEHUNTER.M

\% FLOW CHART OF THE WORKING PRINCIPLE OF A GENETIC ALGORITHM

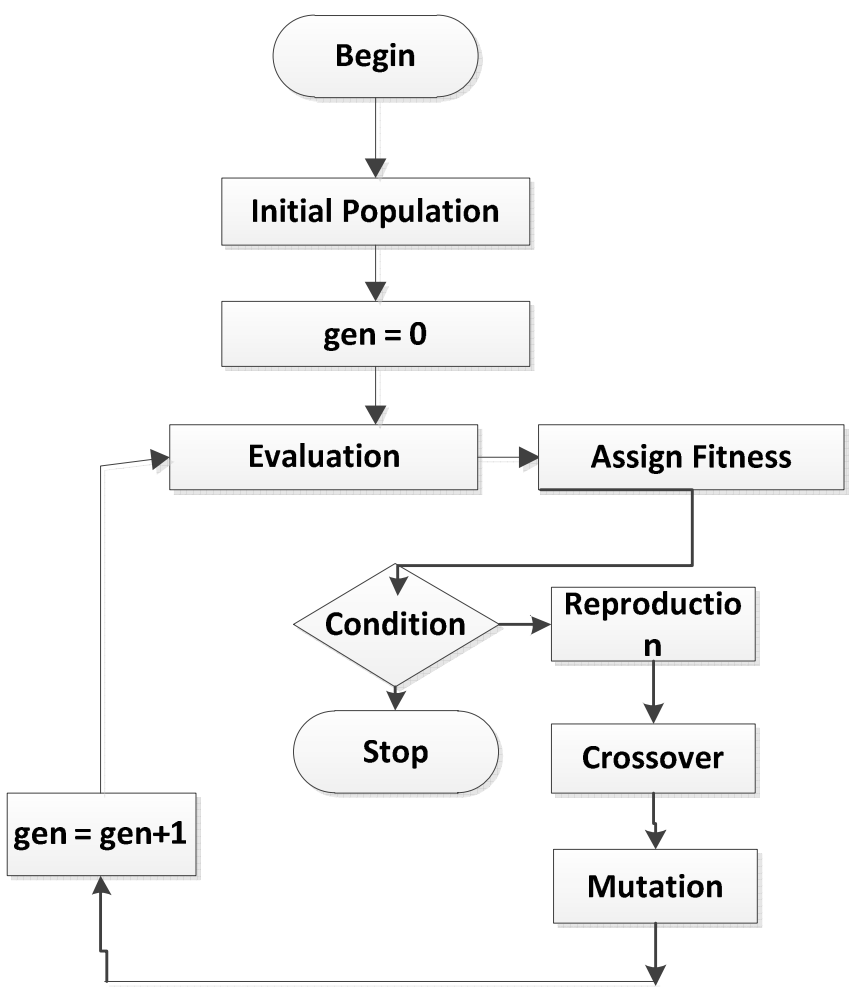

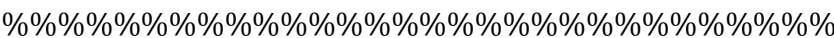
\%\%\%\%\%\%\%\%\%\%\%\%\%\%\%\%\%\%\%\%\%\%\%\%\%\%\%\%\%\% $\% \% \% \% \% \% \% \% \% \% \% \% \% \% \%$

clc

disp(' This is a MATLAB program for ');

disp(' Reliability-based calibration of three-hinge timber '); 
disp(' Portal frame based on Genetic Algorithms '); disp(' Code developed by Dr. Mohammed J. K. ');

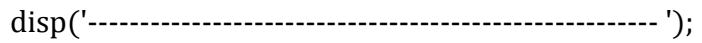

disp(' 1: Reliability/Plasticity Analysis Routine');

$\operatorname{disp}($ ' 2: System Reliability-Based Design ');

$\operatorname{disp}('$ 3: Fire Critical Frame');

disp(' 4: Wind Critical Frame');

disp(' 5: Effect of Varring Load Ratio');

disp(' 6: Effect of Load Contribution');

$\operatorname{disp}(' \quad 7:$ Effect of Changing Load Distribution Model');

disp(' 8: Effect of Changing Resistance Distribution Model');

disp(' 9: Reliability-Based Calibration');

disp(' 10: Effect of Varring Factors of Safety (1) ')

$\operatorname{disp}('$ 11: Effect of Varring Factors of Safety (2) ');

$\operatorname{disp}($ ' 12: Sway Mode Analysis ');

disp(' 13: Plasticity Check (GA Operators) ');

disp(' 14: System Reliability Check ');

disp(' 15: Reliability_based Design (Variation of Load Ratio) ');

disp(' 16: Reliability-Based Analysis Routine (Slenderness Effect) ');

$\operatorname{disp}('$ 17: Calibration(Effect of Material Covariance)');

$\operatorname{disp}($ ' 0: Exit'); $\operatorname{disp}(' \quad$ ');

analysistype $=$ input(' CHOOSE OPTION FROM THE LIST ABOVE: ');

switch analysistype

$\%$

case $0 \%$---- EXIT

$\%$

$\operatorname{disp}($ ' ');

disp(' Bye, bye.');

$\operatorname{disp}($ ' ');

$\%$

case $1 \%$---- RELIABILITY ANALYSIS

$\%$

$\mathrm{Qk}=0.75$;

$\mathrm{WK}=\operatorname{windload}(\mathrm{Z}, \mathrm{BWSPEED}, \mathrm{XL})$

Alpha $=0.8$

$\mathrm{Gk}=\mathrm{QK}+\mathrm{WK}-($ alpha* $\mathrm{QK}+$ alpha*WKw$) ;$

.End 